\title{
Successful management of a child with Kawasaki disease complicated by acute myocardial infarction
}

\author{
Houssem Thabet, Nejeh Ben Halima, Ahmed Sghaier \\ Department of Cardiology, Ibn El jazzar Hospital Kairouan Tunisia, Faculty of Medicine, Souuse, Tunisia
}

ARTICLE INFO

Article history:

Submitted: 28. 2. 2018

Accepted: 29. 5. 2018

Available online: online: 2. 10. 2019

\section{Klíčová slova:}

Infarkt myokardu

Kawasaki

Perkutánní léčba

Tenektepláza

Keywords:

Kawasaki

Myocardial infarction

Percutaneous treatment

Tenecteplase

\section{SOUHRN}

Kawasakiho nemoc je multisystémová akutní vaskulitida. V podstatě se jedná o postižení všech tepen střední velikosti, zvláště věnčitých; což vysvětluje závažnost tohoto onemocnění. I když časná intravenózní aplikace imunoglobulinu snižuje u Kawasakiho nemoci riziko kardiovaskulárních komplikací, u pacientů nereagujících na léčbu může v důsledku trombózy v souvislosti s aneurysmaty v koronárních tepnách dojít k rozvoji infarktu myokardu. Tato kazuistika popisuje úspěšné řešení infarktu myokardu v důsledku trombózy koronární tepny u čtyřletého dítěte, kdy byla intravenózně podána tenektepláza a následně provedena perkutánní koronární intervence.

(c) 2019, ČKS

\section{Introduction}

Kawasaki disease (KD) is an acute, systemic vasculitis of childhood. The early mortality of this disease results from coronary complications, mainly aneurysmal thrombosis with myocardial infarction. ${ }^{1}$ Although there have been reports of ischemic heart disease as late cardiologic sequelae of KD in young adults, acute myocardial infarction caused by coronary complications is rare. The realization of echocardiography is a fundamental step in the diagnostic approach of KD.

\section{Case report}

A 4-year-old male child presented to pediatric emergency with fever and rash. He initially underwent a septic workup, however Kawasaki disease was suspected and the boy was referred for echocardiography which showed a large aneurysm at the origin of the left anterior descen- ding (LAD) coronary artery measuring $6 \mathrm{~mm}$ in diameter and a slight dilatation of the circumflex coronary artery (Circ). The right coronary artery was not dilated. Thus, KD was confirmed and the boy was treated with infusion of intravenous immunoglobulin (IVIG) and high-dose aspirin ( $80 \mathrm{mg} / \mathrm{kg} /$ day). His fever persisted, and he received another dose of IVIG. Despite therapy with IVIG, there was enlargement of his coronary aneurysms reaching $8 \mathrm{~mm}$ and the RCA became dilated measuring $7 \mathrm{~mm}$. Thus he received one pulse of intravenous methylprednisolone. He became apyretic and the inflammatory blood markers decreased significantly. The patient was discharged home on subcutaneous low molecular-weight heparin and aspirin (6 weeks after the beginning of his symptoms).

Two weeks later, he was admitted with chest pain. Anamnesis revealed that anticoagulation therapy had been inadequate during the previous week. The patient underwent an electrocardiogram which was consistent with anterior myocardial ischemia (Fig. 1). The echocardiogram showed apical and septal hypokinesia with poor left ven-

Address: Houssem Thabet, MD, Department of Cardiology, Ibn El jazzar Hospital Kairouan Tunisia, Faculty of Medicine, Souuse, Tunisia,

e-mail: houssem2.thabet@gmail.com

DOI: 10.33678/cor.2019.031 


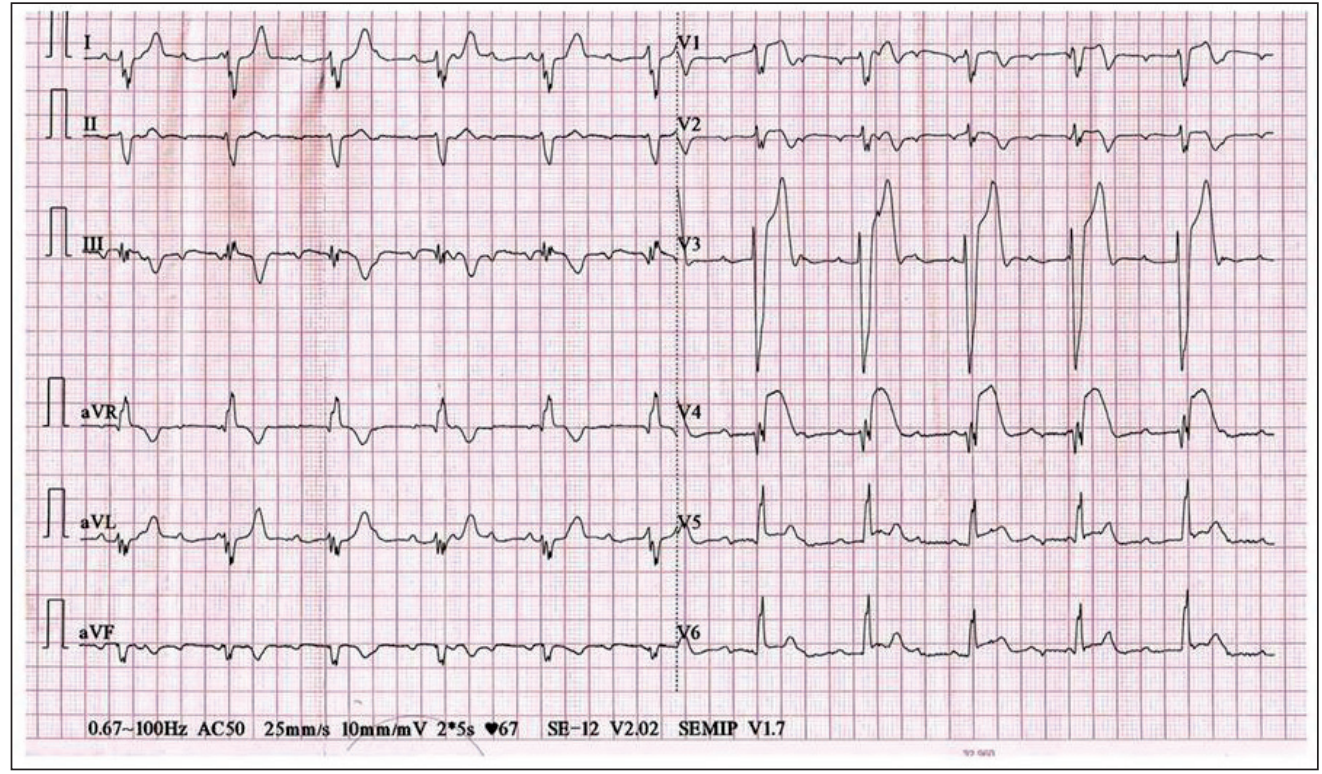

Fig. 1 - Electrocardiogram showing the ST segment elevation in the anterior leads with atrioventricular block
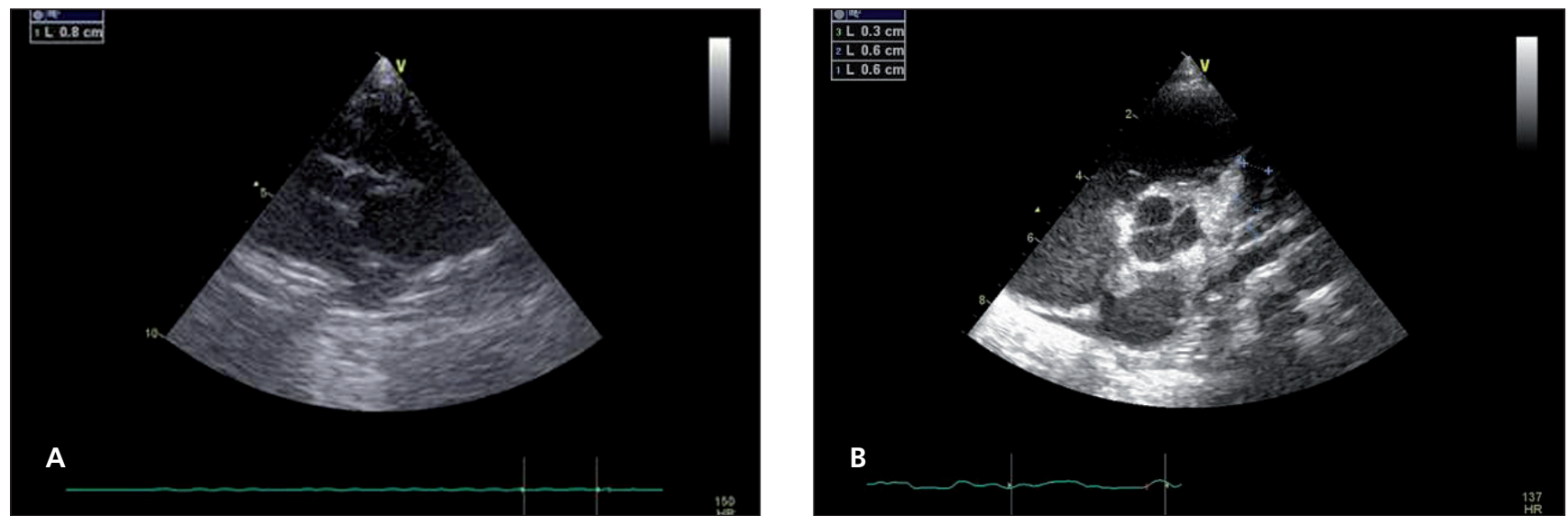

Fig. 2 - Echocardiogram from the parasternal short-axis view showed important right coronary artery dilation (A), left anterior descending artery (LAD) aneurysm, and dilated circumflex coronary artery (B)

tricle function and moderate mitral regurgitation (ejection fraction $=35 \%$ ); dry pericardium (Fig. 2). An aneurysm was present at the origin of the LAD with thrombus occluding the lumen. The RCA and Circ branches were significantly dilated. The patient received $37.5 \mathrm{mg}$ of clopidogrel and he was maintained with a heparin infusion of $15 \mathrm{U} / \mathrm{kg} / \mathrm{h}$. Immediate evolution was marked by the occurrence of complete atrioventricular block. No signs of shock were present. Dobutamine was infused and a 0.7 unit dose of Tenecteplase (metalyse) was infused intravenously then the patient was transferred directly to the cardiac catheterization laboratory for urgent evaluation and treatment.

A left heart catheterization was performed via the right femoral artery. The aortic pressure was 85/55 $\mathrm{mmHg}$. Non-selective angiography of the LCA was performed which showed a complete occlusion of this coronary artery (Fig. 3). Intra left coronary artery infusion of heparin $(50 \mathrm{mg})$ was administered followed by balloon angioplasty. This procedure was well tolerated and re- canalization with complete reperfusion of the occluded artery was immediately achieved. Angiography into the RCA was performed then.

The RCA was severely affected. Aneurysms were present throughout the RCA and distal branches (Fig. 4). The heart block resolved 2 days later, the boy improved clinically and was discharged 15 days later receiving clopidogrel, aspirin and acenocoumarol (minisintrom). The echocardiogram showed improvement of left ventricular contraction reaching $53 \%$ after a few weeks. A cerebral and thoracoabdomino-pelvic CT angiography were performed without abnormalities, as well as a Doppler ultrasound of the lower limb was normal.

\section{Discussion}

Kawasaki disease is a systemic vasculitis of the middle caliber arteries, most commonly reaching the child before 5 years of age. Described in 1967 by T. Kawasaki, ${ }^{2}$ it is 10 

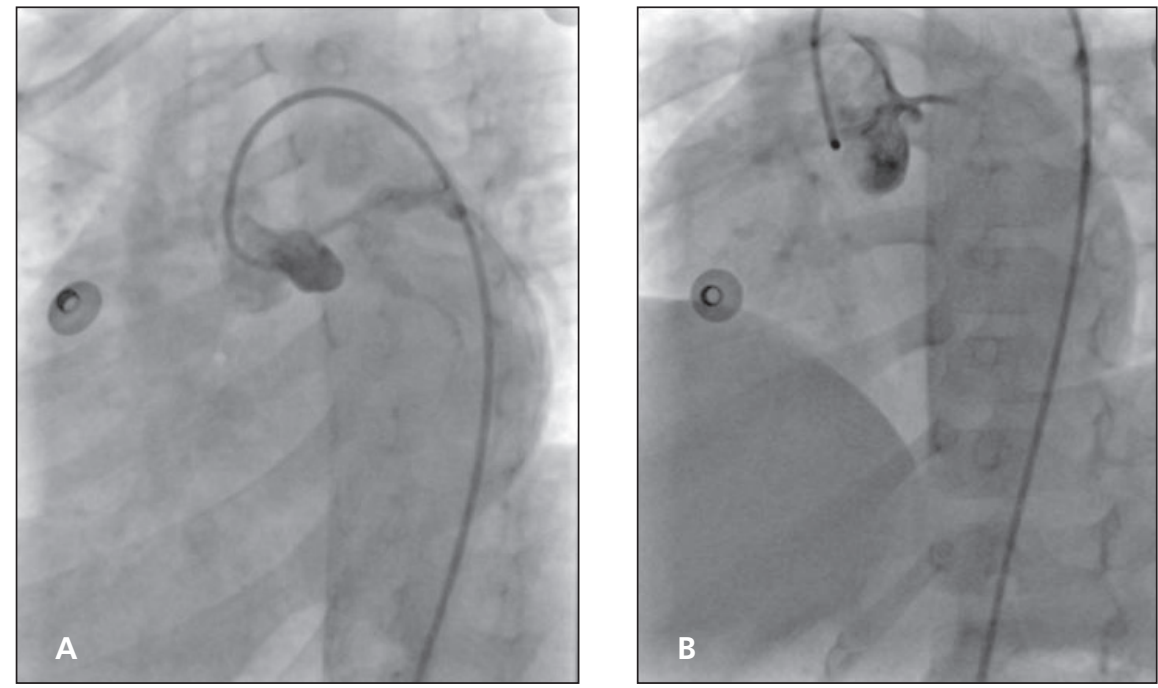

Fig. 3 - Coronary angiogram demonstrated occluded left anterior descending artery $(A)$ that has been repermeabilised after balloon angioplasty (B).

times more common in Japan (112/100 000 children under 5 years/year) than in Western countries, and in the latter, more common in the subjects of Asian origin. ${ }^{3-5}$ The etiology and trigger mechanism of the disease are unknown.

In the absence of a specific biological marker, the diagnosis is based on clinical criteria defined by a committee of experts, ${ }^{6}$ which sometimes appear over time, and may be accompanied by damage to other organs, less frequent, but testifying to the systemic nature of the disease.

Classical criteria associated with five-day fever and constant brutal appearance irritability

- Non-purulent bilateral bulbar conjunctivitis

- Mucous involvement: pharyngitis, cheilitis, raspberry tongue, stomatitis

- Polymorphous exanthemum

- Achievement of the extremities: erythema of the palms of the hands and/or soles of the feet, palmoplantar edema, secondary palmar-plantar desquamation in "finger of glove".

- Unilateral cervical lymph nodes, more than $1.5 \mathrm{~cm}$ in diameter, firm.

The spontaneous evolution of the disease is usually towards the disappearance of fever on the 11th day. Coronary aneurysms occur from the 2 nd week to the 4 th week of evolution, in $20-25 \%$ of untreated cases. But it must be emphasized that there are factors that favor the development of aneurysms which are?

- Age less than 1 year old and over 8 years old

- Male sex

- Fever and prolonged eruption

- Persistence of fever after immunoglobulins requiring a second dose

- Intensity and persistence of inflammatory syndrome, thrombocytosis, anemia, leukocytosis and elevation of CRP

- Presistance of a low albuminemia

The risk of cardiac complications justifies the repetition of systematic echocardiograms: in the first week, at 15 days, 6 to 8 weeks, in search of myocardial, peri- cardial, valvular and especially coronary involvement. ${ }^{8}$ Echocardiography must rigorously analyze each coronary segment (measurement of internal diameter, search for parietal hyperechogenicity), by multiplying the sectional planes and by using high frequency probes. ${ }^{9}$ It allows the detection of $100 \%$ of children with coronary involvement, but remains random in the analysis of the distal, the search for thrombosis or stenosis. ${ }^{10}$ The left coronary artery is affected in $12 \%$ of cases, the right coronary artery in $3 \%$ and the two arteries in $8 \% .{ }^{11}$ We speak of "small" aneurysms whose internal diameter is less than 5 $\mathrm{mm}$, "average", between 5 and $8 \mathrm{~mm}$ and "giant", greater than $8 \mathrm{~mm} .{ }^{11}$

$50 \%$ of coronary aneurysms regress over time (on average in 2 years). But the normalization of the internal diameter of the artery can be due to a parietal thickening, ${ }^{12}$ well visualized by intracoronal ultrasound, ${ }^{13}$ and now the CT scan..$^{14}$ It then persists endothelial dysfunction decreasing the coronary reserve and can make the bed of atherosclerosis. The predictive factors for regression of aneurysms are?

- Small size

- Age < one year old

- Morphiform morphology rather than saccular

- Localization distal

Similarly, if dilation persists, abnormal blood flow may lead to stenosis at the entrance and exit of the aneurysm.

Kato and Tsuda showed, by repeating coronary angiography in patients with coronary aneurysm, that the late onset of stenosis or coronary occlusion was a function of the degree of initial dilatation, and appeared only for coronary diameters exceeding $4 \mathrm{~mm} .{ }^{15-17}$ This is the case of our patient. This potentially stenotic evolution leads to propose to patients with a history of Kawasaki disease with coronary involvement regular cardiac monitoring according to their level of risk, determined by the initial coronary dilation. ${ }^{9}$

This case illustrates a very rare occurrence of an acute myocardial infarction in a pediatric patient. Manage- 


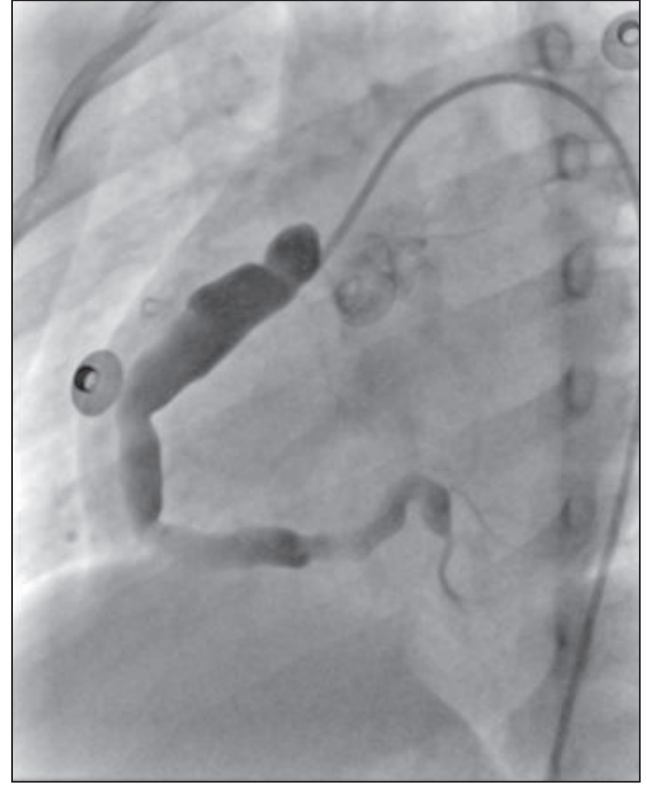

Fig. 4 - Angiography showing total dilation with multiple aneurysms of the right coronary artery

ment of this condition which is commonly encountered in adults but seldom seen in children was challenging. Application of similar principles for a myocardial infarction was empiric. The boy illustrated in this report presented with symptoms rapidly recognized to be very probably due to Kawasaki disease and echocardiography was the imaging modality for confirming the diagnosis by showing coronary aneurysms. After diagnosis, the child did not respond to treatment with two courses of IVIG and he experienced severe coronary involvement. IVIG has a potent anti-inflammatory effect in KD although the mechanisms of action are still unknown .The recommended dose is a single infusion of $2 \mathrm{~g} / \mathrm{kg}$ over a period of 8-12 hours. Among refractory KD patients who receive a second highdose of IVIG, 20 to $50 \%$ of patients develop coronary artery complications. ${ }^{18}$ Large sized coronary aneurysms $(\geq 6$ $\mathrm{mm}$ in diameter) account for approximately $0.5-1.0 \%$ of the total cases of KD. ${ }^{19}$ In these patients, strict control of anti-thrombotic status using combinations of anti-coagulant and antiplatelet medications for at least 3 years after $\mathrm{KD}$ onset is essential.

However, in KD patients with giant coronary aneurysms, thrombus formation is occasionally seen despite the use of antithrombotic agents. ${ }^{20}$ Myocardial infarction is very rare in children. There are no controlled trials or specific recommendations to guide early treatment in this age group and the use of thrombolytics in children is commonly met with anxiety and an appropriate concern for bleeding complications, limiting the number of children who may benefit from early therapy. However, there has been little clinical experience with the use of thrombolytic therapy in children with KD.

This experience involved the intravenous administration of streptokinase and urokinase and tissue plasminogen activator (TPA), as well as the monoclonal platelet glycoprotein (GP) Ilb/llla receptor inhibitor, abciximab. Also, improved outcome was reported when thrombolytic agents were administered directly into the coronary arteries. Tsubata et al..$^{21}$ infused TPA at a dose of 50,000 U/ $\mathrm{kg}$ into the RCA and LCA and of a 7-month-old boy with massive thrombi and decreased LV function. The thrombi decreased in size, and the LV function returned to normal with no complications. Sohn and Kwon ${ }^{22}$ infused 1 $\mathrm{mg} / \mathrm{kg}$ of TPA into the coronary artery of a 7-year-old boy with resolution of the ischemia. To the best of our knowledge this is the first use of tenecteplase for KD in children. There were no bleeding complications from this medication and it would have been more efficient to administrate thrombolytic therapy into the coronary artery instead of heparin. However, intravenous thrombolysis also facilitated the percutaneous intervention and it is likely that this patient would not have survived without this immediate rapid therapy.

Percutaneous coronary interventions can be considered although there may be difficulties in successfully passing a guidewire through an occluded aneurysm. Balloon angioplasty may not yield a durable result, and it does not seem easy that a stent could be deployed within an acutely occluded aneurysm. The experience in literature is very scarce. Consequently, either intracoronary thrombolysis or intravenous coronary thrombolysis must be the therapeutic strategy for AMI in children. Severe complications are uncommon and do not require special facilities. ${ }^{23}$

\section{Conclusion}

This case illustrates the importance of synergistic teamwork among pediatric intensive care, and both pediatric congenital and adult interventional cardiology when encountering coronary artery disease in pediatric patients. Physicians should carefully monitor KD patients who do not respond to initial IVIG therapy and show progressive coronary artery dilatation. Coronary thrombosis must be treated aggressively with thrombolytic and platelet inhibitor to rescue the myocardium by reestablishing coronary perfusion.

\section{Conflict of interest}

The author declared no potential conflicts of interest with respect to the research, authorship, and/or publication of this article.

\section{References}

1. McCrindle BW, Rowley AH, Newburger JW, et al. Diagnosis, Treatment, and Long-Term Management of Kawasaki Disease: A Scientific Statement for Health Professionals From the American Heart Association. Circulation 2017;136:e927-e999.

2. Kawasaki T. Acute febrile MCLNS. Clinical observations of 50 cases. Jpn J Allerg 1967;16:178-222.

3. Yanagawa $H$, Nakamura $Y$, Yashiro $M$, et al. Incidence survey of Kawasaki disease in 1997 and 1998 in Japan. Pediatrics 2001;107:E33.

4. Holman RC, Curns AT, Belay ED, et al. Kawasaki syndrome hospitalizations in the United States, 1997 and 2000. Pediatrics 2003;112:495-501.

5. Davis RL, Waller PL, Mueller BA, et al. Kawasaki syndrome in Washington State. Race-specific incidence rates and residential proximity to water. Arch Pediatr Adolesc Med 1995;149:66-69.

6. Rauch AM, Hurwitz ES. Center for Disease Control (CDC) case definition for Kawasaki syndrome. Pediatr Infect Dis 1985;4:702-703. 
7. Mori M, Imagawa T, Yasui K, et al. Predictors of coronary artery lesions after intravenous gamma-globulin treatment in Kawasaki disease. J Pediatr 2000;137:177-180.

8. Davis RL, Waller PL, Mueller BA, et al. Kawasaki syndrome in Washington State. Race-specific incidence rates and residential proximity to water. Arch Pediatr Adolesc Med 1995;149:66-69.

9. Hiraishi S, Misawa H, Takeda N, et al. Transthoracic ultrasonic visualisation of coronary aneurysm, stenosis, and occlusion in Kawasaki disease. Heart 2000;83:400-405.

10. Capannari TE, Daniels SR, Meyer RA, et al. Sensitivity, specificity, and predictive value of two-dimensional echocardiography in detecting coronary artery aneurysms in patients with Kawasaki disease. J Am Coll Cardiol 1986;7:355360.

11. Newburger JW, Takahashi M, Gerber MA, et al. Committee on Rheumatic Fever, Endocarditis and Kawasaki Disease; Council on Cardiovascular Disease in the Young; American Heart Association; American Academy of Pediatrics. Diagnosis, treatment, and longterm management of Kawasaki disease: a statement for health professionals from the Committee on Rheumatic Fever, Endocarditis and Kawasaki Disease, Council on Cardiovascular Disease in the Young, American Heart Association. Circulation 2004; 110:2747-2771.

12. Sasaguri $Y$, Kato H. Regression of aneurisms in Kawasaki disease: a pathological study. J Pediatr 1982;100:225-231.

13. Sugimura $T$, Kato $H$, Inoue $O$, et al. Intravascular ultrasoud of coronary arteries in children. Assessment of the wall morphology and the lumen after Kawasaki disease. Circulation 1994;89:258-265.

14. Sohn S, Kim HS, Lee SW. Multidetector row computed tomography for follow-up of patients with coronary artery aneurysms due to Kawasaki disease. Pediatr Cardiol 2004;25:35-39.

15. Kato H, Ichinose E, Yoshioka F. Fate of coronary aneurysms in Kawasaki disease: serial coronary angiography and long-term follow-up study. Am J Cardiol 1982;49:1758-1766.

16. Tsuda E, Kamiya T, Kimura K, et al. Coronary artery dilatation exceeding $4.0 \mathrm{~mm}$ during acute Kawasaki disease predicts a high probability of subsequent late intima-medial thickening. Pediatr Cardiol 2002;23:9-14.

17. Tsuda E, Kamiya $T$, Ono $Y$, et al. Incidence of stenotic lesions predicted by acute phase changes in coronary arterial diameter during Kawasaki disease. Pediatr Cardiol 2005;26:73-79.

18. Hashino $K$, Ishii $M$, lemura $M$, et al. Re-treatment for immuneglobulin resistant Kawasaki disease: a comparative study of additional immune globulin and steroid pulse therapy. Pediatr Int 2001;43:211-217.

19. Uehara R, Belay ED. Epidemiology of Kawasaki disease in Asia, Europe, and the United States. J Epidemiol 2012;22:79-85.

20. Kato $H$, Ichinose $E$, Kawasaki T. Myocardial infarction in Kawasaki disease: clinical analyses in 195 cases. J Pediatr 1986;108:923-927.

21. Tsubata S, Ichida Fl, Hamamichi Y, et al. Successful thrombolytic therapy using tissuetype plasminogen activator in Kawasaki disease. Pediatr Cardiol 1995;16:186-189.

22. Sohn S, Kwon K. Accelerated thrombotic occlusion of a medium-sized coronary aneurysm in Kawasaki disease by the inhibitory effect of ibuprofen on aspirin. Pediatr Cardiol 2008;29:153-156.

23. Crystal MA. Thrombolytic Use in Children: Breaking Down Barriers. J Pediatr 2016;171:12-13. 